\title{
OBITUARY.
}

\section{SIR CHARLES SEELY, BART.}

We deeply regret to record the death of Sir Charles Seely, Bart., at Brook House, Isle of Wight, on the I6th April, aged 81, from heart trouble.

Sir Charles Seely joined the Society in 1908. As he never took any active part in aeronautics his support of this Society must be accounted one of those kindly and generous actions for which he was noteworthy. His eldest son, $\mathrm{Mr}$. Charles Hilton Seely, formerly M.P. for Lincoln, and also a member of this Society, succeeded to the baronetcy and estates.

We deeply regret to have to record the deaths of the following members on active service:-

\section{LIEUTENANT-COMMANDER C. G. W. HEAD, R.N.}

Clement Gordon Wakefield Head, Lieut.-Com., R.N., youngest and only surviving son of Mr. and Mrs. J. J. Head, of Seaford, Sussex, was lost in his submarine on the Ist December, 1914, aged 29. He had been a member of the Society since 1909, and would undoubtedly have won in the Air Service, had he chosen to leave the Submarine Service, an equally high reputation to that which he had gained in the latter Service.

\section{SECOND LIEUTENANT S. P. COCKERELL, R.F.C.}

Samuel Pepys Cockerell, Second Lieutenant, Royal Flying Corps, Military Wing, died in Egypt on the 2oth March, r9I5, suddenly, of acute smallpox, aged 34. Lieutenant Cockerell joined the Society in I9I I, the year in which he took his pilot's certificate. He joined the R.F.C. in January, 1913, and was appointed to active service soon after the outbreak of war.

\section{CAPTAIN A, G. FOX, R.E.}

Alan Geoffrey Fox, Captain, R.E., aged 27, only surviving son of Mr. and Mrs. Charles Fox, 3o, Ladbrooke Gardens, W., died of wounds sustained whilst carrying out an important bomb attack behind the German lines, on $9^{\text {th }}$ May, 1915.

Captain Fox joined the Society in $191 \mathrm{I}$, when in the old Air Battalion, and played an important part in the development of the Royal Flying Corps from that embryo service. He was mentioned in despatches for his work in the present campaign:

\section{MAJOR B. H. BARRINGTON-KENNETT.}

Basil Herbert Barrington-Kennett, Major, 2nd Grenadier Guards, was shot while leading his men against the Germans on I8th May, I9I5.

Major Barrington-Kennett joined the Society in 191r. Like Captain Fox, he played an important part in the development of the Royal Flying Corps from the old Air Battalion. In I9I 2 he won the Mortimer Singer prize for the longest flight by an Army officer, by flying with a passenger, on a Nieuport monoplane, a distance of $249 \frac{1}{2}$ miles. For some time he was Adjutant of the R.F.C. at Farnborough, in which capacity his singular personal charm stood him in good stead. When war broke out he was appointed to the Staff as Deputy Assistant Adjutant and Quartermaster-General, subsequently leaving the R.F.C. to serve with his regiment, the Grenadier Guards. Major Barrington-Kennett married a few years ago. Mrs. Barrington-Kennett, to whom all sympathy will be extended, has done much valuable work on the Flying Corps Aid Committee. 